\title{
Phylogenetic analysis of Bacteroidales 16S rRNA gene sequences from human and animal effluents and assessment of ruminant faecal pollution by real-time PCR
}

\author{
S. Mieszkin, J.-F. Yala, R. Joubrel and M. Gourmelon
}

EMP, Laboratoire de Microbiologie, Ifremer, Plouzané, France

*: Corresponding author : M. Gourmelon, email address : Michele.Gourmelon@ifremer.fr

\begin{abstract}
:
Aims: The aims of this study were to evaluate the host-specific distribution of Bacteroidales 16S rRNA gene sequences from human- and animal-related effluents and faeces, and to define a ruminantspecific marker.

Methods and Results: Bacteroidales 16S rRNA gene clone libraries were constructed from samples of effluent (sewage, bovine manure and pig slurry) and faeces (human, bovine, pig and wild bird), using PCR primers targeting order Bacteroidales. The phylogenetic analysis revealed six main distinct human-, bovine-, pig- and wild bird-specific clusters. From the bovine-specific cluster II, we designed a ruminant-specific marker, Rum-2-Bac, and this showed $97 \%$ sensitivity $(n=30)$ and $100 \%$ specificity $(n=40)$ when tested by TaqMan ${ }^{\circledR}$ real-time PCR. Average concentrations of this marker in bovine and sheep faeces and in bovine manure were $8.2 \pm 0.5,8.4 \pm 1.3$ and $7 \pm 0.5 \log _{10}$ copies per gram, respectively. It was also quantified in samples of runoff water impacted by bovine manure, with average concentrations of $5 \cdot 1 \pm 0 \cdot 3 \log _{10}$ copies per millilitre water.
\end{abstract}

Conclusions: Our results confirmed that some members of Bacteroidales isolated from effluents and faeces had host-specific distributions. Identification of a bovine-specific cluster made it possible to design a reliable ruminant-specific marker.

Significance and Impact of the Study: The host-specific distribution of Bacteroidales sequences from effluents mirrored the host-specific distribution of sequences observed in individual faeces. This efficient new ruminant-specific Bacteroidales 16S rRNA marker represents a useful addition to the microbial source tracking toolbox.

Keywords: 16S rRNA gene • Bacteroidales • faecal contamination • Microbial Source Tracking • sewage and manure 


\section{Introduction}

Human and animal faecal pollution affects environmental water quality in both inland and coastal areas, with negative implications for recreational uses, public safety and shellfish sanitary status (Feldhusen, 2000; Gourmelon et al. 2006; Dorfman and Sinclair Rosselot 2008). Such pollution can also lead to economic losses if there are shellfish market closures or restrictions on bathing (Rabinovici et al. 2004).

France is an important animal producer in the European Union. It is the top cattle producer and ranks third for pig production. Indeed, in 2006, more than 19.5 million cattle and 14.8 million pigs were reared in France. Brittany and Normandy account for $10.5 \%$ and $11.7 \%$ of total national cattle production (Agreste Scees 2007). Furthermore, in Normandy, the presence of sheep on salt meadows could lead to human health risks in coastal waters (Hubbard et al. 2004). The coastal areas of these regions are thus particularly sensitive to animal faecal pollution. Bovine faecal contamination can arise due to slurry or manure spreading on arable land, cattle grazing or drinking near rivers, or stock movements.

Due to difficulties in the identification of non-point sources and the combined presence of urban and agricultural activities on some watersheds, Microbial Source Tracking (MST) methods are crucial for effective resource management and remediation. Many MST techniques have been developed to discriminate between human and non-human sources of faecal contamination, and to distinguish contamination from different animal species (Wiggins 1996; Parveen et al. 1999; Bernhard and Field 2000a and b; USEPA 2005). These methods aim to detect microbial or chemical targets associated with human and animal faeces, or sewage- or animal-related effluents (Marvin et al. 2001; Glassmeyer et al. 2005). Among these methods, the detection of host-specific bacterial genetic markers such as Bacteroidales 16S rRNA genes in DNA extracts is a promising method. Detection of these anaerobic bacteria was proposed as an alternative and possibly superior water quality indicator (Fiksdal et al. 1985), as this group represents the main component of human and animal flora. Members of Bacteroidales are present at high concentrations in faeces (e.g. about $10^{9}-10^{11}$ per $\mathrm{g}$ of human faeces) but do not maintain culturability for very long once released into fresh or marine waters, due to their low oxygen tolerance (Allsop and Stickler; 1985; Fiskdal et al. 1985). Furthermore, some faecal members of Bacteroidales are described as having host species-specific or group-specific distributions (Kreader 1995; Bernhard and Field, 2000b). To quantify the relative contributions of specific hosts in an environmental sample, real-time PCR assays have recently been developed targeting human-specific (Seurinck et al. 2005; Layton et al. 2006; Kildare et al. 2007; Okabe et al. 2007; Reischer et al. 2007), ruminant-specific (Layton et al. 2006; Reischer et al. 2006) and pig-specific (Okabe et al. 2007; Mieszkin et al. 2009) Bacteroidales markers. As preliminary assays in our laboratory with previously developed ruminant-specific Bacteroidales markers showed some lack of specificity on pig or human feacal samples from France with these primer sets, we decided to develop a new ruminant-specific marker. Furthermore, identification of partial Bacteroidales 16S rRNA gene sequences from hosts in different locations is still needed to improve host-specific Bacteroidales PCR assays. Moreover there are few Bacteroidales sequences obtained from effluents or, particularly, from animal waste such as slurries or manure, available in databases. Designing host-specific markers based on sequences obtained from this kind of sample should improve the efficiency of 16S rRNA genetic markers for identifying faecal contamination in the environment.

The aims of this study were (i) to determine host-specific Bacteroidales 16S rRNA gene sequence distribution with sequences isolated from wastewater treatment plants (WWTP) water, bovine manure and pig slurry samples, and from human, bovine, pig and wild bird faeces; (ii) to design new primers and a probe to quantify the ruminant-specific Bacteroidales 16S rRNA gene by TaqMan ${ }^{\circledR}$ analysis; and (iii) to validate this marker on samples of runoff water impacted by bovine manure.

To our knowledge, this is the first study on the distribution of Bacteroidales 16S rRNA gene sequences that focuses on sewage and animal waste samples. 


\section{Materials and methods}

Sample collection

To consider Bacteroidales from human and animal sources at the individual and population level, a total of 82 faeces and 52 effluent samples were collected from August 2004 to April 2008 in France.

Faecal samples

Human faeces were obtained from 17 healthy adult and child volunteers from Brittany. Animal faeces were collected immediately after excretion from apparently healthy animals (19 cows, 10 sheep, 10 horses, 16 pigs, and 10 wild birds). Cow faeces were sampled from animals kept on pasture or housed in stalls on 6 farms in Brittany and Normandy. Sheep faeces were collected from one farm in Brittany and from salt meadows on two farms in Normandy. Horse faeces were collected from stud farms in Brittany and Pays de la Loire. Pig faeces were collected from sows, adult males, young pigs and piglets mainly housed in stalls on 7 farms in Brittany. Wild bird faeces were collected mainly from seagulls, gulls, Eurasian widgeon, and brent goose on two beaches in Brittany.

Effluent and water samples

Ten WWTP water samples were collected at the outlets of 10 independent municipal WWTP not connected to slaughterhouses, in Brittany, Normandy and Pays de la Loire. Twenty bovine manure and 10 pig slurry samples were collected from 11 independent farms in Brittany.

For the run-off experiments, bovine manure with a concentration of $30 \mathrm{t}$ per ha was spread on experimental arable land $(75 \mathrm{~cm}$ by $150 \mathrm{~cm})$. Runoff water samples were collected after 15 and 120 min of rainfall simulations with a rainfall intensity ranging from 50 to $55 \mathrm{~mm}$ per hour, corresponding to a storm event. A total of 12 field runoff water samples were collected, either previously spread with bovine manure (6 samples) or left as an untreated control (6 samples). Rain was simulated by watering with deep well water used, which was also sampled for testing.

All samples were placed in sterile containers and transported to the laboratory in insulated coolers. Faeces and bovine manure samples were aliquoted and cells from water and effluent samples were captured on filters upon arrival at the laboratory. All the samples were then stored at $-20^{\circ} \mathrm{C}$ until analysis.

Sample preparation and DNA extraction

For faeces and bovine manure samples, DNA was extracted from $250 \mathrm{mg}$ wet weight of sample using the Fast DNA Spin Kit for Soil (MP Biomedical, Illkirsh, France), according to Dick et al. (2005). Pig slurry and runoff water samples $(50 \mathrm{ml})$ were centrifuged at $9000 \times \mathrm{g}$ for 15 minutes and DNA extracted from $250 \mathrm{mg}$ of the pellet using the Fast DNA Spin Kit for Soil. For WWTP water samples, $20-100 \mathrm{ml}$ were filtered through $0.22 \mu \mathrm{m}$ Nuclepore membrane filters (Whatman, Boumath, France), respectively. Filters were then placed in 0.5 $\mathrm{ml}$ of GITC buffer (5 M guanidine isothiocyanate, $100 \mathrm{mM}$ EDTA [pH = 8.0], 0.5\% Sarkosyl) and kept frozen at $-20^{\circ} \mathrm{C}$ until extraction (Dick and Field 2004). DNA was then extracted using the DNeasy Tissue Kit (Qiagen, Courtaboeuf, France) as described in Dick and Field (2004).

PCR and 16S rRNA gene library construction

The primers Bac32F and Bac708R (Bernhard and Field, 2000b) were used to selectively amplify Bacteroidales 16S rRNA genes from DNA extracted from $n=10$ samples each of human, porcine, bovine and wild bird faeces; WWTP water, pig slurry and bovine manure. 
Two microlitres of DNA extracts were added to a $40 \mu$ l-reaction mixture containing $1 \mathrm{X}$ PCR buffer (Roche Diagnostics, Meylan, France), $200 \mu \mathrm{M}$ of each deoxynucleotide triphosphate, $0.5 \mu \mathrm{M}$ of each primer, $2 \mathrm{mM} \mathrm{MgCl}$ and $1 \mathrm{U}$ Taq DNA polymerase (Roche Diagnostics). Reactions were carried out for 30 cycles of $94{ }^{\circ} \mathrm{C}$ for $30 \mathrm{~s}, 61^{\circ} \mathrm{C}$ for $30 \mathrm{~s}$ and $72{ }^{\circ} \mathrm{C}$ for $30 \mathrm{~s}$ in a Peltier Thermal Cycler (PTC 200; MJ Research, Waltham, MA, USA), apart from the DNA from wild bird faeces. To obtain enough PCR products from wild bird faeces, 40 cycles of amplification were needed. Positive (DNA from faeces previously found positive) and negative (water) controls were included in each experiment. PCR products obtained from each library, which were then pooled to obtain seven clone libraries, were gel purified (Nusieve GTG agarose 2\%; BMA, Rockland, USA) using the QiaQuick gel purification kit (Qiagen, France). Libraries were cloned into the pCR2.1 vector using the TOPO TA cloning kit (Invitrogen) according to the manufacturer's instructions. The vectors were transformed into chemically competent Escherichia coli (E. coli) cells (One Shot TOP10F; Invitrogen). Ninety-six transformants from each host-specific library were randomly picked on LuriaBertani (LB) agar plates and used to inoculate 96-well culture plates (Deep-Well; Millipore) containing one $\mathrm{ml}$ LB $2 X$ broth with ampicillin $\left(50 \mu \mathrm{g} \mathrm{ml}^{-1}\right)$. Culture plates were incubated at $37^{\circ} \mathrm{C}$ for $24 \mathrm{~h}$ with shaking $(130 \mathrm{rpm})$. After centrifugation, they were stored at $-20^{\circ} \mathrm{C}$ until the plasmid purification step, performed with the Plasmid Miniprep 96 Kit (Millipore), 3 the inserts were then sequenced.

Sequencing and phylogenetic analysis

Sequencing was performed on an ABI PRISM 9700 capillary sequencer using the ABI Prism Big Dye Terminator Cycle sequencing kit with M13-f and M13-r primers, as described by the manufacturer (Perkin-Elmer Applied Biosystems).

Sequences were edited using BioEdit (Hall, 1999). DNA sequences (approximately $690 \mathrm{bp}$ ) were processed using MALLARD software (Ashelford et al. 2006) to eliminate chimeric sequences. Sequences were aligned using MAFFT (version 5) and the distance matrix calculated using DNADIST (version 3.5c). This matrix was used with DOTUR software (Shloss and Handelsman 2005) to assign sequences to operational taxonomic units (OTUs). OTUs were defined by assigning 16S rRNA gene sequences of $>98 \%$ similarity to the same species. Representative OTU sequences were retrieved rationally with the pipeline application RapidOTU (Legrand et al. 2008) and were compared with the GenBank database (http://www.ncbi.nlm.nih.gov/) using BLAST. Sixty-five uncultured Bacteroidales sequences isolated from human and animal effluent sources (bovine manure, pig slurry and sewage) from the GenBank database were added. Multiple alignments were performed with CLUSTAL W (Thompson et al. 1997). A phylogenetic tree was constructed using PHYLOWIN (Galtier et al. 1996). The root was determined using the 16S rRNA gene sequence of Cytophaga fermentans (M58766) as an outgroup. Distance trees were constructed using Neighbour-Joining algorithms (Saitou and Nei 1987) with the Kimura two-parameter correction (Kimura 1980). The statistical significance of tree branches was evaluated by bootstrap analysis using 500 resamplings.

Oligonucleotide primers and probes

The ruminant-specific Bacteroidales primers and probe (Rum-2-Bac) was designed from multiple alignments of partial Bacteroidales 16S rRNA gene sequences obtained in this study (Table 1). The primers and probe All-Bacteroidales (AllBac) from Layton et al. (2006) was used to amplify total Bacteroidales 16S rRNA genes. Oligonucleotide specificity for ruminantassociated Bacteroidales 16S rRNA genes was verified using the BLAST (NCBI) and Probe Match (Ribosomal Database Project: RDP II) programs.

Table 1: Oligonucleotide sequences and amplification conditions for conventional and realtime PCR assays 


\begin{tabular}{|c|c|c|c|c|c|c|}
\hline $\begin{array}{l}\text { Primers } \\
\text { and } \\
\text { Probes }\end{array}$ & $\begin{array}{l}\text { Primer and probe sequence } \\
\left(5^{\prime} \rightarrow 3^{\prime}\right)^{*}\end{array}$ & $\begin{array}{l}\text { Size of } \\
\text { amplic } \\
\text { on } \\
\text { (bp) }\end{array}$ & $\begin{array}{l}\text { Anneali } \\
\text { ng } \\
\text { Temp.( } \\
\left.{ }^{\circ} \mathrm{C}\right)\end{array}$ & $\begin{array}{l}\text { Final } \\
\text { concentrat } \\
\text { ion } \\
(\mathrm{nmol})\end{array}$ & Target & $\begin{array}{l}\text { Refere } \\
\text { nce }\end{array}$ \\
\hline $\begin{array}{l}\text { Bac32F } \\
\text { Bac708R }\end{array}$ & $\begin{array}{l}\text { AACGCTAGCTACAGGCTT } \\
\text { CAATCGGAGTTCTTCGTG }\end{array}$ & 690 & 60 & $\begin{array}{l}500 \\
500\end{array}$ & $\begin{array}{l}\text { All } \\
\text { Bacteroida } \\
\text { les }\end{array}$ & $\begin{array}{l}\text { Bernha } \\
\text { rd and } \\
\text { Field } \\
\text { 2000a }\end{array}$ \\
\hline $\begin{array}{l}\frac{\text { AllBac }}{\text { AllBac296 }} \\
\text { F } \\
\text { AllBac467 } \\
\text { R } \\
\text { AllBac375 } \\
\text { Bhqr } \\
\text { Rum-2- }\end{array}$ & $\begin{array}{l}\text { GAGAGGAAGGTCCCCCAC } \\
\text { CGCTACTTGGCTGGTTCAG } \\
\text { (FAM)CCATTGACCAATATTCCTCA } \\
\text { CTGCTGCT(BHQ-1) }\end{array}$ & 106 & 60 & $\begin{array}{l}200 \\
200 \\
100\end{array}$ & $\begin{array}{l}\text { All } \\
\text { Bacteroida } \\
\text { les }\end{array}$ & $\begin{array}{l}\text { Layton } \\
\text { et al. } \\
2006\end{array}$ \\
\hline $\begin{array}{l}\text { Bac } \\
\text { BacB2- } \\
590 F \\
\text { Bac708Rm } \\
\text { BacB2- } \\
626 P\end{array}$ & $\begin{array}{l}\text { ACAGCCCGCGATTGATACTGGTA } \\
\text { A } \\
\text { CAATCGGAGTTCTTCGTGAT } \\
\text { (FAM)ATGAGGTGGATGGAATTCG } \\
\text { TGGTGT(BHQ-1) }\end{array}$ & 99 & 60 & $\begin{array}{l}200 \\
200 \\
200\end{array}$ & $\begin{array}{l}\text { Ruminant- } \\
\text { specific } \\
\text { Bacteroida } \\
\text { les }\end{array}$ & $\begin{array}{l}\text { This } \\
\text { study }\end{array}$ \\
\hline
\end{tabular}

${ }^{\bar{F}} \mathrm{FAM}, 6$-carboxyfluorescein; BHQ-1, black hole quencher 1

Real-time PCR assays

All real-time PCR were performed using the $\operatorname{TaqMan}^{\circledR}$ Brilliant II QPCR Master Mix kit (Stratagene). Amplifications were performed using a Stratagene MX $3000 \mathrm{P}$ with software version 4. Each reaction was run in duplicate with the following cycle conditions: 1 cycle at $95^{\circ} \mathrm{C}$ for $10 \mathrm{~min}$ followed by 40 cycles of $95^{\circ} \mathrm{C}$ for $15 \mathrm{~s}, 60^{\circ} \mathrm{C}$ for $1 \mathrm{~min}$. TaqMan reactions were carried out in a final volume of $25 \mu \mathrm{l}$ with appropriate final concentrations of the primers and probe (Table 1).

The presence/absence of PCR inhibitors was verified using an Internal Positive Control (IPC; Applied Biosystems, France). Samples were diluted if inhibitors were present. Negative controls (no template DNA) were performed in triplicate for each run.

The sensitivity and the specificity of the ruminant-specific Bacteroidales marker (Rum-2-Bac) was tested on target DNA $(n=30)$ represented by bovine and sheep faeces and by bovine manure samples and non target DNA $(n=40)$ represented by human, pig, horse and wild bird faeces and by pig slurry samples.

DNA standard curves and quantification

Linear plasmid DNA used to generate standard curves was extracted with the QIAquick Miniprep Extraction Kit (Qiagen), following the manufacturer's instructions. The linear forms of bovine plasmid were obtained with Notl enzyme (Roche Diagnostics) in a final volume of $50 \mu \mathrm{l}$ for $3 \mathrm{~h}$ at $37^{\circ} \mathrm{C}$. For the quantification of Bacteroidales markers, standard curves were generated from serial dilutions of a known concentration of plasmid DNA. Standard curves were generated by plotting threshold cycles (Ct) against 16S rRNA gene copy numbers.

For Rum-2-Bac and AllBac, bovine plasmid DNA containing partial 16S rRNA, gene sequence inserts were used as standards at 10-fold dilutions ranging from $1.6 \times 10^{7}$ to $1.6 \times$ $10^{\circ}$ copies per real-time PCR, with a quantification limit of 1.6 target copies per reaction. 
Consequently, the lower quantification limit of both the ruminant-specific Bacteroidales and All-Bacteroidales markers was $4.5 \log _{10}$ copies per $g$ in faeces. For the runoff experiments, the lower quantification limit of the markers was $2.9 \log _{10}$ copies per millilitre.

Data treatment

The results of general and ruminant-specific Bacteroidales marker quantifications were expressed in 16S rRNA gene copies per $\mathrm{g}$ of faeces or bovine manure and per $\mathrm{ml}$ of runoff water.

To evaluate the performance of the ruminant-specific marker on faecal samples, sensitivity ( $r$ ) and specificity (s) were defined as $r=a /(a+c)$ and $s=d /(b+d)$, where $a$ is the number of faecal samples that were positive for the marker of their own species (true positive); $b$ is the number of faecal samples that were positive for a marker of another species (false positive); $c$, is the number of faecal samples that were negative for a marker of their own species (false negative); and $d$ is the number of faecal samples that were negative for a marker of another species (true negative) (Fisher and Van Bell 1993).

Nucleotide sequence accession numbers

Sequence data used in this study has been submitted to the GenBank database under numbers EU797125 to EU797175 and EU913511 to EU913643.

\section{Results}

Sequence and phylogenetic analysis

From a total of 672 clones sequenced from the seven clone libraries, 594 partial Bacteroidales 16S rRNA gene sequences were obtained. One hundred and seventeen sequences were identified as potentially chimeric and were removed from the phylogenetic analysis. The final analysis contained 477 unambiguous sequences corresponding to 185 OTUs

(Table 2).

Analysis of Bacteroidales 16S rRNA genes from human and animal effluent and faeces samples

Table 2 presents the number of sequences and OTUs, obtained from each type of faeces or effluent sample, shown the similarities of the OTUs to sequences from the NCBI database. Pig faeces and slurry are different from the other samples, as their Bacteriodales were predominantly Prevotella-like rather than Bacteroides-like.

Finally, most of the OTUs isolated from a host were similar to sequences isolated from the same origin found in the Genbank database. For example, of the 27 OTUs isolated from pig faeces, $60 \%$ were closest to sequences from Genbank database isolated from pig sources whereas $26 \%$ were closest to sequences from human sources. 
Table 2: Distribution and characterization of Bacteroidales operational taxonomic units (OTUs) from French samples of faeces and effluents

\begin{tabular}{|c|c|c|c|c|c|c|c|}
\hline $\begin{array}{l}\text { Types of } \\
\text { samples }\end{array}$ & $\begin{array}{l}\text { Main } \\
\text { host- } \\
\text { sources } \\
\text { of the } \\
\text { samples }\end{array}$ & $\begin{array}{l}\text { Seq } \\
*(n)\end{array}$ & $\begin{array}{l}\text { OTUs } \\
\text { (n) }\end{array}$ & $\begin{array}{c}\% \text { of OUT with } \\
<98 \% \\
\text { similarity to } \\
\text { GenBank } \\
\text { sequences } \\
\end{array}$ & $\begin{array}{c}\text { Bacteroides- or } \\
\text { Prevotella-like } \dagger \\
\text { (\%) }\end{array}$ & $\begin{array}{l}\text { Host-sources of } \\
\text { sequences from } \\
\text { GenBank } \text { closest to } \\
\text { OTUs with } 100 \% \\
\text { similarity }\end{array}$ & References \\
\hline \multirow[t]{4}{*}{ Faeces } & Human & 73 & 16 & 94 & Bacteroides (94) & $\begin{array}{l}\text { 82\% Human; } \\
\text { 12.5\% Turkey }\end{array}$ & $\begin{array}{l}\text { Eckburg et al. 2005; } \\
\text { Manichanh et al. 2008; } \\
\text { Scupham } 2007\end{array}$ \\
\hline & Bovine & 75 & 37 & 58 & Bacteroides (89) & $\begin{array}{l}\text { 92\% Ruminant; } \\
\text { 8\% Environmental }\end{array}$ & $\begin{array}{l}\text { Dick et al. 2005; } \\
\text { Layton et al. 2006; } \\
\text { Bernhard and Field 2000a }\end{array}$ \\
\hline & Pig & 63 & 27 & 33 & Prevotella (85) & $\begin{array}{l}60 \% \text { Pig; } \\
26 \% \text { Human }\end{array}$ & $\begin{array}{l}\text { Leser et al. 2002; } \\
\text { Dick et al. 2005; } \\
\text { Eckburg et al. } 2005\end{array}$ \\
\hline & Wild bird & 61 & 15 & 45 & Bacteroides (87) & $\begin{array}{l}\text { 40\% Chicken; } \\
\text { 33\% Human; } \\
\text { 13\% Horse; } \\
\text { 13\% Environmental }\end{array}$ & $\begin{array}{l}\text { Layton et al. 2006; } \\
\text { Scupham 2007; } \\
\text { Eckburg et al. 2005; } \\
\text { Simpson et al. 2004; } \\
\text { Lamendella et al. } 2007\end{array}$ \\
\hline \multirow[t]{3}{*}{ Effluents } & $\begin{array}{l}\text { WWTP } \\
\text { waters }\end{array}$ & 68 & 30 & 70 & Bacteroides (67) & $\begin{array}{l}\text { 57\% Human; } \\
\text { 27\% Ruminant; } \\
\text { 10\% Dog }\end{array}$ & $\begin{array}{l}\text { Ley et al. 2006; Li et al. } \\
2008 \\
\text { Ley et al. 2008; } \\
\text { Layton et al. } 2006\end{array}$ \\
\hline & $\begin{array}{l}\text { Bovine } \\
\text { manure }\end{array}$ & 79 & 36 & 57 & Bacteroides (92) & $\begin{array}{l}\text { 78\% Ruminant; } \\
\text { 22\% Environmental }\end{array}$ & $\begin{array}{l}\text { Layton et al. 2006; } \\
\text { Ueki et al. } 2008\end{array}$ \\
\hline & Pig slurry & 58 & 24 & 60 & Prevotella (55) & $\begin{array}{l}55 \% \text { Pig; } \\
13 \% \text { Environmental }\end{array}$ & $\begin{array}{l}\text { Leser et al. 2002; } \\
\text { Dick et al. 2005; } \\
\text { Eckburg et al. 2005; } \\
\text { Okabe et al. } 2007\end{array}$ \\
\hline Total & & 477 & 185 & & & & \\
\hline
\end{tabular}

WWTP: Wastewater Treatment Plant.

*Seq: unambiguous sequences.

†From RDPII (>98\% similarity) ‡From NCBI with Blast program. 
Distribution of Bacteroidales 16S rRNA OTUs in host-specific clusters and design of ruminant-specific Bacteroidales marker

Phylogenetic analysis of the Bacteroidales OTUs identified in this study and the Bacteroidales sequences isolated from human and animal effluents from the Genbank database showed six main distinct host-specific clusters with sequences from both effluent and faeces samples (Fig. 1). Several clusters containing sequences from multiple faecal sources were also identified in the phylogenetic tree.

For reasons of clarity of presentation, only 22 and 17 OTUs from bovine and pig faeces, respectively, were included in the phylogenetic tree.

Two human-specific clusters were distinguished, HUMAN I and II, which contained 12 and 5 OTUs, respectively. The HUMAN I cluster contained the 'Fhc 10' OTU, which was 99\% identical to Bacteroides thetaiotaomicron (AE015928), and the 'Fhc17' and 'STEPc48' OTUs, which were 99\% identical to Bacteroides ovatus (AY652736, EU722734 and DQ100446). The HUMAN II cluster contained the OTUs 'Fhc31' and 'STEPc77', which were 100\% identical to cultured Bacteroides vulgatus (EU728705, and EU136687 and CP000139, respectively). The 'Fhc11' and 'STEPc81' OTUs were 100\% and 99\% identical to cultured bacteria Bacteroides dorei (EU722737), respectively, and $99 \%$ identical to the clones 'HF145' and 'HF8' (Bernhard and Field 2000a; AF233408 and AF233411), respectively. This cluster also contained four sequences isolated from human sewage samples (EU573838, EU573839, EU573847 and EU573852).

One pig-specific cluster was identified: PIG. This cluster contained 10 OTUs, of which OTU 'Fpc8' was 99\% identical to the clone 'PigC1' (AY695691) described by Dick et al. (2005). The OTUs 'Fpc35' and 'Fpc3' were closer to clones 'P93' (AB237869) and 'P80' (AB237867) obtained by Okabe et al. (2007) (96\% and 94\% similarity, respectively). This cluster also contained three sequences isolated from aerated pig manure slurry samples (AB331475, AB331465 and AB331464).

Only one cluster was identified for wild bird Bacteroidales OTUs, WILD BIRD, which contained seven OTUs.

Two bovine-specific clusters were isolated, BOVINE I and II, which contained 10 and 24 OTUs, respectively. The BOVINE I cluster contained one sequence isolated from a continuously stirred tank reactor of bovine waste samples (EU551115). The BOVINE II cluster contained 1 OTU, 'Fbc86', which was 97\% identical to the clone 'CF123' (Bernhard and Field 2000a; AF233400). This cluster was used to design a ruminant-associated realtime PCR assay that we named Rum-2-Bac.To validate this PCR assay, oligonucleotide specificity for ruminant-associated Bacteroidales 16S rRNA genes were tested in silico using the BLAST (NCBI) and Probe Match (RDP II) programs. The primer BacB2-590F and the probe BacB2-626P were found highly specific to ruminant source.

Figure 1: Phylogenetic relationships of 185 operational taxonomic units from partial Bacteroidales 16S rRNA gene sequences isolated from effluent samples (WWTP water, STEPc; bovine manure, Fubc; and pig slurry, Lpc) and faeces (human, Fhc; bovine, Fbc; wild bird, Foc; and pig, Fpc). The scale bar represents $2.8 \%$ sequence divergence. Bootstrap values were calculated with 500 resamplings, and values below $75 \%$ were omitted. The $16 \mathrm{~S}$ rRNA gene sequence from Cytophaga fermentans (M58766) was used as an outgroup for rooting the tree. Uncultured Bacteroidales isolated from faecal and effluent origin and sequences of cultivated and described Bacteroides and Prevotella species obtained from GenBank were also included. 
Determination of faecal concentration of general and ruminant-specific Bacteroidales markers in effluent and faeces

Table 3 presents the percentage of positive results and average concentrations of ruminantspecific and general Bacteroidales markers in human and animal faeces and bovine manure.

The Rum-2-Bac marker showed $97 \%$ sensitivity $(n=30)$ and $100 \%$ specificity $(n=40)$. Average concentrations of the Rum-2-Bac marker obtained on bovine and sheep faeces were similar $\left(8.2 \pm 0.5\right.$ and $8.4 \pm 1.3 \log _{10}$ copies per $\mathrm{g}$, respectively) whereas in bovine manure, average concentration was lower with $7 \pm 0.5 \log _{10}$ copies per $\mathrm{g}$. No amplification was observed with DNA from human, horse, pig and wild bird faeces samples.

The average concentrations of the All-Bacteroidales marker in faeces samples ranged between $5.3 \pm 1.1 \log _{10}$ copies per $\mathrm{g}$ in wild bird faeces to $10.2 \pm 0.5 \log _{10}$ copies per $\mathrm{g}$ in human faeces. Furthermore, for one faeces sample from a seagull, no amplification was obtained. For bovine manure samples, average concentrations of the All-Bacteroidales marker were $9.6 \pm 0.3 \log _{10}$ copies per g (Table 3 ).

Table 3: Quantification of All-Bacteroidales (AllBac) and ruminant-specific markers in faecal and effluent samples; percentage of positive samples and concentrations

\begin{tabular}{|c|c|c|c|c|}
\hline \multirow[b]{2}{*}{ Samples } & \multicolumn{2}{|l|}{ AllBac } & \multicolumn{2}{|l|}{ Rum-2-Bac } \\
\hline & $\begin{array}{l}\text { Positive samples } \\
\text { (\%) }\end{array}$ & Concentration* & $\begin{array}{l}\text { Positive } \\
\text { (\%) }\end{array}$ & Concentration \\
\hline Bovine faeces $(n=10)$ & 100 & $9.8 \pm 0.2$ & 100 & $8.2 \pm 0.5$ \\
\hline Sheep faeces $(n=10)$ & 100 & $9.8 \pm 0.9$ & 100 & $8.4 \pm 1.3$ \\
\hline Horse faeces $(n=10)$ & 100 & $8.8 \pm 0.3$ & 0 & $<4.5$ \\
\hline Pig faeces $(n=10)$ & 100 & $10.1 \pm 0.8$ & 0 & $<4.5$ \\
\hline Human faeces $(n=10)$ & 100 & $10.2 \pm 0.5$ & 0 & $<4.5$ \\
\hline Wild bird faeces $(n=10)$ & 90 & $5.3 \pm 1.1$ & 0 & $<4.5$ \\
\hline Bovine manure $(n=10)$ & 100 & $9.6 \pm 0.3$ & 90 & $7 \pm 0.5$ \\
\hline
\end{tabular}

* Concentrations are expressed in $\log _{10}$ copies per gram in faeces and bovine manure samples

Application of general and ruminant-specific Bacteroidales markers in runoff waters impacted by bovine manure

Run-off experiments were performed in order to test the capacity of the ruminant-specific marker to be detected after storm events in run-off waters from arable land where bovine manure had previously been spread. The ruminant-specific and general Bacteroidales markers were quantified in runoff waters impacted by bovine manure, giving with mean estimated concentrations of $5.1 \pm 0.3$ and $7.1 \pm 0.5 \log _{10}$ copies per $\mathrm{ml}$ of water, respectively. In the control runoff water, all the results with the Rum-2-Bac and AllBac markers were below the quantification limit $\left(2.9 \log _{10}\right.$ copies per mlilitre).

\section{Discussion}

Coastal waters and rivers can be contaminated in multiple ways, especially by human sources, farm animals and wildlife (Griffin et al. 2001; Shanks et al. 2006; Savichtcheva et al. 2007). While wild bird droppings from roosting seagulls and faeces from pastured cattle have been described as potential sources of faecal pollution, municipal wastewater effluents and bovine or pig slurry manure spreading on arable land are also known to be also important sources of faecal contamination (Griffin et al. 2001; Savichtcheva et al. 2007; Lu et al. 2008). Bacteroidales have previously been noted to have several desirable characteristics as faecal 
source identifiers, including the possibility of quantitative assessment, broad geographic stability and broad distribution in target host animals (USEPA, 2005).

Our work has provided interesting data on Bacteroidales 16S rRNA gene diversity among different hosts, by identifying 185 OTUs and six host-specific clusters (two for human, two for bovine, one for pig and one for wild bird). Interestingly, all human-, bovine- and pig-specific Bacteroidales 16S rRNA gene sequence clusters identified contained sequences from both effluents and faeces. These results suggest that i) some host-specific Bacteroidales $16 \mathrm{~S}$ rRNA gene sequences identified in faeces could still be present in effluents (Peu et al. 2006) and ii) they could persist in the environment, even after a passage though the sewage network, or stockage/treatment of these wastes (Kreader, 1998; Peu et al. 2006; Okabe and Shimazu 2007).

Most Bacteroidales OTUs identified were not closely related to cultured bacteria species, indicating a high level of (as yet uncultured) diversity, as observed by Dick et al. (2005), Layton et al. (2006) and Okabe et al. (2007). In contrast, some OTUs from humans were found to be $>99 \%$ identical to sequences of cultured Bacteroides, as in Dick et al. (2005). However, as Bacteroides-related sequences from bird, cat and dog faeces were also closely related to these sequences, cultured Bacteroidales do not seem to be efficient MST targets.

Compared to high number of 16S rRNA gene sequences isolated from faeces samples in the database, there are few Bacteroidales sequences isolated from effluent samples and still fewer derived from animal wastes (Whitehead et al. 2005; Shipin et al. 2007; Ueki et al. 2008; Hanajima et al. 2009). Phylogenetic analysis with effluent sequences from this study and database supported the host specificity of the clusters. Furthermore, some of the sequences found to be host-specific in this study were also found specific to the same host in geographic areas other than France, such as the United States or Japan (Bernhard and Field 2000b; Okabe et al. 2007). For example, the HUMAN II cluster contained four sequences, present in the Genbank database, that had been isolated from sewage in Ireland, and the clones 'HF8' and 'HF145', isolated in the United States, that were used to design the humanspecific HF 183 marker (Bernhard and Field 2000b; Seurinck et al. 2005). The PIG cluster contained sequences that were used to design the pig-specific markers in the studies of Okabe et al. (2007) and Mieszkin et al. (2009).

These results suggest the existence of host-specific Bacteroidales sequences with a broad geographic distribution. One explanation for the presence of host-specific Bacteroidales could be the differences in digestive tract physiology and diet of humans and animal species, rather than the physiology of these hosts (Dick et al. 2005).

This study also provided data on the presence of Bacteroidales in different faecal samples. Indeed, all samples tested were found to contain Bacteroidales, and quantitative results were obtained on these samples (except for one seagull faeces sample) by performing AllBacteroidales real-time PCR assays. All-Bacteroidales marker concentrations were similar in bovine faeces and manure and in horse, sheep, pig and human faeces whereas lower concentrations were obtained in wild bird faeces. A lower level of Bacteroidales in wild bird samples than in other origin faeces has already been observed in previous studies. For example, no positive results on wild bird faeces by conventional PCR assay were observed by Fogarty and Voytek (2005). Furthermore, Lu et al. (2003; 2008) by phylogenetic analysis of faecal flora, demonstrated that Bacteroidales are poorly represented in avian faeces (about 1\%), while Lactobacillaceae (70\%) and Clostridiaceae (11\%) are dominant.

The ruminant-specific marker (Rum-2-Bac), which we developed from the bovine-specific cluster Bovine II, was quantified in bovine and ovine faecal samples suggesting that this marker could be used to detect bovine and sheep faecal contamination that arises in the coastal environment due to grazing alongside rivers and on salt meadows. This marker represents $1-5 \%$ of the total Bacteroidales populations in bovine and sheep feces samples. These results are similar of those that we obtained for the human-specific Bacteroidales marker developed by Seurinck et al. (2005) and for the two pig-specific Bacteroidales markers developed by Mieszkin et al. (2009). Furthermore, the high Rum-2-Bac marker concentrations obtained in all bovine manure samples showed that this marker is reliable for investigating faecal pollution from bovine manure spread on arable land. Indeed, this marker 
was detected and quantified in water samples impacted by bovine manure (concentration 30 $\mathrm{t} \mathrm{ha}^{-1}$ ) during runoff simulations with a rain intensity corresponding to a storm event.

The Rum-2-Bac marker was not amplified in horse faeces suggesting that this marker is able to discriminate between horse and cattle faecal pollution.

The design of a new ruminant-specific Bacteroidales 16S rRNA gene marker to discriminate ruminant faecal contaminations from other faecal sources represents an efficient tool for a microbial source tracking toolbox to improve and monitor water quality in watersheds and coastal areas impacted by faecal pollution.

\section{Acknowledgements}

This work was partly supported by the French agency AFSSET (Agence Française de Sécurité Sanitaire de l'Environnement et du Travail). Sequencing was performed at OuestGénopole platform. We thank Dr A. Jaffrezic for the experimental runoff simulations and S. Lozach and $\mathrm{P}$. Bodenes for technical assistance. S. Mieszkin was supported by a grant from Ifremer and Région Bretagne.

\section{References}

Agreste Scees (2007) Statistique agricole annuelle: Résultats 2006. Chiffres et données Agriculture, no. 191.

Allsop, K. and Stickler, D. J. (1985) An assessment of Bacteroides fragilis group organisms as indicators of human faecal pollution. J Appl Bacteriol 58, 95-99.

Ashelford, K. E., Chuzhanova, N. A., Fry, J. C., Jones, A. J. and Weightman, A. J. (2006) New screening software shows that most recent large 16S rRNA gene clone libraries contain chimeras. Appl Environ Microbiol 72, 5734-5741.

Bernhard, A. E. and Field, K. G. (2000a) Identification of nonpoint sources of fecal pollution in coastal waters by using host-specific $16 \mathrm{~S}$ ribosomal DNA genetic markers from fecal anaerobes. Appl Environ Microbiol 66, 1587-1594.

Bernhard, A. E. and Field K. G. (2000b) A PCR assay to discriminate human and ruminant feces on the basis of host differences in Bacteroides-Prevotella genes encoding 16S rRNA. Appl Environ Microbiol 66, 4571-457.

Dick, L. K., Bernhard, A. E., Brodeur, T. J., Santo Domingo, J. W., Simpson, J. M., Walters, S. P. and Field, K. G. (2005) Host distributions of uncultivated fecal Bacteroidales bacteria reveal genetic markers for fecal source identification. Appl Environ Microbiol 71, 3184-3191.

Dick, L. K., and Field, K. G. (2004) Rapid estimation of numbers of fecal Bacteroidales by use of a quantitative PCR assay for 16S rRNA genes. Appl Environ Microbiol 70, 5695-5697.

Dorfman, M. and Sinclair Rosselot, K. (2008) Testing the waters 2008: A guide to water quality testing at vacation beaches. Washington D.C., Natural Resources Defense Council.

Eckburg, P. B., Bik, E. M., Bernstein, C. N., Purdom, E., Dethlefsen, L., Sargent, M., Gill, S. R., Nelson, K. E. and Relman D. A. (2005) Diversity of the human intestinal microbial flora. Science 308, 1635-1638.

Feldhusen, F. (2000) The role of seafood in bacterial foodborne diseases. Microbes Infect $\mathbf{2}$, 1651-1660.

Fiksdal, L., Maki, J. S., LaCroix, S. J. and Staley, J. T. (1985) Survival and detection of Bacteroides spp., prospective indicator bacteria. Appl Environ Microbiol 49, 148-150.

Fisher, L. D. and Van Belle, G. (1993) Biostatistics: a methodology for health sciences. Wiley, New York, NY.

Fogarty, L. R. and Voytek, M. A. (2005) Comparison of Bacteroides-Prevotella 16S rRNA genetic markers for fecal samples from different animal species. Appl Environ Microbiol 71, 5999-6007. 
Galtier, N., Gouy, M. and Gautier, C. (1996) SEAVIEW and PHYLO_WIN: two graphic tools for sequence alignment and molecular phylogeny. Comput Appl Biosci 12, 543-548.

Glassmeyer, S. T., Furlong, E. T., Kolpin, D. W., Cahill, J. D., Zaugg, S. D., Werner, S. L., Meyer, M. T. and. Kryak, D. D. (2005). Transport of chemical and microbial compounds from known wastewater discharges: potential for use as indicators of human fecal contamination. Environ. Sci.Technol. 39, 5157-5169.

Gourmelon, M., Montet, M. P., Lozach, S., Le Mennec, C., Pommepuy, M., Beutin, L. and Vernozy-Rozand, C. (2006) First isolation of Shiga toxin 1d producing Escherichia coli variant strains in shellfish from coastal areas in France. J Appl Microbiol 100, 85-97.

Griffin, D. W., Lipp, E. K., McLaughlin, M. R. and Rose, J. B. (2001) Marine recreation and public health microbiology: quest for the ideal indicator. Bioscience 51, 817-825.

Hall, T. A. (1999) BioEdit: A user-friendly biological sequence alignment editor and analysis program for Windows 95/98/NT. Nucleic Acids Symp Ser 41, 95-98.

Hanajima, D., Haruta, S., Hori, T., Ishii, M., Haga, K. and Igarashi, Y. (2009) Bacterial community dynamics during reduction of odorous compounds in aerated pig manure slurry. $\mathrm{J}$ Appl Microbiol 106. 118-129.

Hubbard, R. K., Newton, G. L. and Olson, B. H. (2004) Water quality and the grazing animal. J Anim Sci. 82, E255-E263.

Katoh, K., Misawa, K., Kuma, K. and Miyata, T. (2002) MAFFT: a novel method for rapid multiple sequence alignment based on fast Fourier transform. Nucl Aeido Res 30, 30593066.

Kildare, B.J., Leutenegger, C.M., McSwain, B.S., Bambic, D.G., Rajal, V.B. and Wuertz, S. (2007) 16S rRNA-based assays for quantitative detection of universal, human-, cow-, and dog-specific fecal Bacteroidales: a Bayesian approach. Water Res 41, 3701-3715.

Kimura, M. (1980) A simple model for estimating evolutionary rates of base substitutions through comparative studies of nucleotide sequences. J Mol Evol 16, 111-120.

Kreader, C. A. (1995) Design and evaluation of Bacteroides DNA probes for the specific detection of human fecal pollution. Appl Environ Microbiol 61, 1171-1179.

Kreader, C. A. (1998) Persistence of PCR-detectable Bacteroides distasonis from human feces in river water. Appl Environ Microbiol 64, 4103-4105.

Lamendella, R., Domingo, J. W., Oerther, D. B., Vogel, J. R. and Stoeckel, D. M. (2007) Assessment of fecal pollution sources in a small northern-plains watershed using PCR and phylogenetic analyses of Bacteroidetes 16S rRNA gene. FEMS Microbiol Ecol. 59, 651-600.

Layton, A., McKay, L., Williams, D., Garrett, V., Gentry, R. and Sayler, G. (2006) Development of Bacteroides 16S rRNA gene TaqMan-Based real-time PCR assays for estimation of total, human, and bovine fecal pollution in water. Appl Environ Microbiol 72, 4214-4224.

Legrand, L., Tap, J., Gauthey, C., Doré, J., Caron, C. and Leclerc, M. (2008) RapidOTU: a fast pipeline to analyse 16S rRNA sequences by alignment or tetranucleotide frequency. Proc. Gut Microbiome Symp. $20086^{\text {th }}$ Congr. Clermont-Ferrand, France: INRA Rowett Res. Inst., poster 26, p. 35.

Leser, T. D., Amenuvor, J. Z., Jensen, T. K., Lindecrona, R. H., Boye, M. and Moller, K. (2002) Culture-independent analysis of gut bacteria: the pig gastrointestinal tract microbiota revisited. Appl Environ Microbiol 68, 673-690.

Ley, R. E., Hamady, M., Lozupone, C., Turnbaugh, P. J., Ramey, R. R.,Bircher, J. S., Schlegel, M. L., Tucker, T. A., Schrenzel, M. D., Knight, R. and Gordon, J. I. (2008) Evolution of mammals and their gut microbes. Science 320, 1647-1651.

Ley, R. E., Turnbaugh, P. J., Klein, S. and Gordon, J. I. (2006) Microbial ecology: human gut microbes associated with obesity. Nature 444, 1022-1023.

Li, M., Wang, B., Zhang, M., Rantalainen, M., Wang, S., Zhou, H., Zhang, Y., Shen, J., Pang, X., Zhang, M., Wei, H., Chen, Y., Lu, H., Zuo, J., Su, M., Qiu, Y., Jia, W., Xiao, C., Smith, L. M., Yang, S., Holmes, E., Tang, H., Zhao, G., Nicholson, J. K., Li, L. and Zhao, L. (2008) Symbiotic gut microbes modulate human metabolic phenotypes. Proc Natl Acad Sci USA $105,2117-2122$. 
Lu, J., Idris, U., Harmon, B., Hofacre, C., Maurer J. and Lee, M. D. (2003) Diversity and succession of the intestinal bacterial community of the maturing broiler chicken. Appl Environ Microbiol 69, 6816-6824.

Lu, J., Santo Domingo, J. W., Lamandella, R., Edge, T. and Hill, S. (2008) Phylogenetic diversity and molecular detection of bacteria in Gull feces. Appl Environ Microbiol 74, 39693976.

Manichanh, C., Chapple, C. E., Frangeul, L., Gloux, K., Guigo, R. and Dore, J. (2008) A comparison of random sequence reads versus $16 \mathrm{~S}$ rDNA sequences for estimating the biodiversity of a metagenomic library. Nucleic Acids Res 36, 5180-5188.

Marvin, C., Coakley, J., Mayer, T., Brown, M. and Thiessen, L. (2001) Application of fecal sterol ratios in sediments and effluents as source tracers, Water Qual Res J Can 36, 781792.

Mieszkin, S., Furet, J. P., Corthier, G. and Gourmelon, M. (2009) Estimation of pig fecal contamination in a river catchment by real-time PCR using two pig-specific Bacteroidales 16S rRNA genetic markers. Appl Environ Microbiol 75, 3045-3054.

Okabe, S., Okayama, N., Savichtcheva, O. and Ito, T. (2007) Quantification of host-specific Bacteroides-Prevotella 16S rRNA genetic markers for assessment of fecal pollution in freshwater. Appl Microbiol Biotechnol 74, 890-901.

Okabe, S. and Shimazu, Y. (2007) Persistence of host-specific Bacteroides-Prevotella 16S rRNA genetic markers in environmental waters: effects of temperature and salinity. Appl Microbiol Biotechnol 76, 935-944.

Parveen, S., Portier, K. M., Robinson, K. Edminston, L. and Tamplin, M. L. (1999) Discriminant analysis of ribotype profiles of Escherichia coli for differentiating human and non human sources of fecal pollution. Appl Environ Microbiol 65, 3142-3147.

Peu, P., Brugère, H., Pourcher, A. M., Kérourédan, M., Godon, J. J., Delgenès, J. J. and Dabert, P. (2006) Dynamics of a pig slurry microbial community during anaerobic storage and management. Appl Environ Microbiol 72, 3578-3585.

Rabinovici, S. J., Bernknopf, R. L., Wein, A. M., Coursey, D. L. and Whitman, R. L. (2004) Economic and health risk trade-offs of swim closures at a Lake Michigan beach. Environ Sci Technol 38, 2737-2745.

Reischer, G. H., Casper, D. C., Steinborn, R., Mach, R. L. and Farnleitner, A. H. (2006) Quantitative PCR method for sensitive detection of ruminant fecal pollution in freshwater and evaluation of this method in Alpine karstic regions. Appl Environ Microbiol 72, 5610-5614.

Reischer, G.H., Casper, D.C., Steinborn, R., Farnfeitner, A.H. and Nach, R.L. (2007) A quantitative real-time PCR assay for the highly senstive detection of human faecal influence in spring water from a large alpine cachment area. Lett Appl Microbiol 44, 351-356.

Saitou, N. and Nei, M. (1987) The neighbor-joining method: a new method for reconstructing phylogenetic trees. Mol Biol Evol 4, 406-425.

Savichtcheva, O., Okayama, N. and Okabe, S. (2007) Relationships between Bacteroides 16S rRNA genetic markers and presence of bacterial enteric pathogens and conventional fecal indicators. Water Res 41, 3615-3628.

Scupham, A. J. (2007) Succession in the intestinal microbiota of preadolescent turkeys. FEMS Microbiol Ecol 60, 136-147.

Seurinck, S., Defoirdt, T., Verstraete, W. and Siciliano, S. D. (2005) Detection and quantification of the human-specific HF183 Bacteroides 16S rRNA genetic marker with realtime PCR for assessment of human faecal pollution in freshwater. Environ Microbiol 7, 249259.

Shanks, O. C., Nietch, C., Simonich, M., Younger, M., Reynolds, D. and Field, K. G. (2006) Basin-wide analysis of the dynamics of fecal contamination and fecal source identification in Tillamook bay, Oregon. Appl Environ Microbiol 72, 5537-5546.

Shipin, O. V., Lee, S. H., Chiemchaisri, C., Wiwattanakom, W., Ghosh, G. C., Anceno, A. J. and Stevens, W. F. (2007) Piggery wastewater treatment in a tropical climate: biological and chemical treatment options. Environ Technol 28, 329-337. 
Shloss P. D. and Handelsman, J. (2005) Introducing DOTUR, a computer program for defining operational taxonomic units and estimating species richness. Appl Environ Microbiol 71, 1501-1506.

Simpson, J. M., Santo Domingo, J. W. and Reasoner, D. J. (2004) Assessment of equine fecal contamination: the search for alternative bacterial source-tracking targets. FEMS Microbiol Ecol 47, 65-75.

Thompson, J. D., Gibson, T. J., Plewniak, F., Jeanmougin, F. and Higgins, D. G. (1997) The CLUSTAL_X windows interface: flexible strategies for multiple sequence alignement aided by quality analysis tools. Nucleic Acids Res 25, 4876-4882.

Ueki, A., Abe, K., Kaku, N., Watanabe, K. and Ueki, K. (2008) Bacteroides propionicifaciens sp. nov., isolated from rice-straw residue in a methanogenic reactor treating waste from cattle farms. Int J Syst Evol Microbiol 58, 346-352.

U.S. Environmental Protection Agency (USEPA). (2005) Microbial Source Tracking Guide Document. Washington, DC: EPA Office of Research and Development.

Whitehead, T. R., Cotta, M. A., Collins, M. D., Falsen, E. and Lawson, P. A. (2005) Bacteroides coprosuis sp. nov., isolated from swine-manure storage pits. Int J Syst Evol Microbiol 55, 2515-2518.

Wiggins, B. A. (1996) Discriminant analysis of antibiotic resistance patterns in fecal streptococci, a method to differentiate human and animal sources of fecal pollution in natural waters. Appl Environ Microbiol 62, 3997-4002. 